\title{
Level of Metacognitive Awareness Strategies among Technical Students
}

\author{
Yee, M. H, Zainol, N. S. I, Che Wan Razak, C.W.H.S, Tee, T. K, Kok, B. C
}

\begin{abstract}
Metacognitive strategy awareness is important to solve many problems especially in the teaching and learning process as well as in one's career. This survey aims to identify the level of metacognitive awareness strategies among polytechnic students according to demographics, and also the difference between the level of metacognitive awareness strategies based on gender and the field of study of students. The sample of the study consists of 361 students who attended Diploma in Civil Engineering (132 students), Diploma in Electrical Engineering (121 students) and Diploma in Mechanical Engineering (108 students). The design of this study is survey using the quantitative approach. The research instrument used is the Metacognitive Strategies Awareness Inventory (MAI) with two main constructs, knowledge of cognitive and regulation of cognitive. These are used to determine the level of metacognitive awareness strategies. All data was analyzed using SPSS software and presented in the form of mean score, frequency and percentage. The results show that all male and female students have high level in metacognitive strategies awareness. The T-Test analysis shows that there is a significant difference in the level of awareness of metacognitive strategies between male and female students ( $\rho$ $=.021<.05)$. Furthermore, the ANOVA test analysis also shows that there is a significant difference in the level of awareness of metacognitive strategies based on the field of study of the students $(\rho=.016<.05)$. Therefore, it can be concluded that the awareness of metacognitive strategies should be applied to students to produce effective teaching and improve students' learning achievement.
\end{abstract}

Key word: Metacognitive strategy awareness, problem solving

\section{INTRODUCTION}

The increasingly challenging level of economic performance requires a paradigm shift that will help keep the economy stable and stably in tandem with developed countries (Ibrahim \& Iksan, 2017). Therefore, the government has to create a generation that is innovating and competitive in various aspects, especially in education, economy and technology. The change in global education also emphasizes on cognitive strategies to metacognitive strategies has shown an impact on the implementation of teaching and learning (Kassim \& Zakaria, 2015). Subsequently, $21^{\text {st }}$-century learning involves emphasizing

Revised Manuscript Received on September 22, 2019.

Yee, M. H., Department of Engineering Education, UTHM, Batu Pahat, Malaysia.

Zainol, N. S. I, Faculty of Technical and Vocational Education, UTHM, Batu Pahat, Malaysia.

Che Wan Razak, C. W. H. S., Faculty of Technical and Vocational Education, UTHM, Batu Pahat, Malaysia.

Tee, T, K, Department of Technical Education , UTHM, Batu Pahat, Malaysia

Kok, B. C. Department of Electrical Engineering, UTHM, Batu Pahat, Malaysia metacognitive strategies (Ibrahim \& Iksan, 2017). According to Surat (2013), metacognitive strategies can help students manage learning processes such as monitoring, planning, process evaluation and outcomes of their learning achievement. According to Coffey (2009), this metacognitive strategy can allow students the opportunity to reflect on their learning, through the process of identifying strengths and weaknesses, as well as ways for students to learn, to set goals and to control their way of learning.

Students who master the metacognitive strategy well will be able to solve various problems, dilemmas and questions that are beyond their thinking or habits. This is because, this process will encourage student self-learning and help to acquire good learning among students (Zimmerman \& Schunk, 2011). Metacognitive strategies also relate to the process of improving thinking skills through assessment skills, regulation (Surat, 2012) monitor and plan (Sima Khezrlou, 2012). Metacognitive strategies can also help students in controlling their learning and teaching process (Surat, 2013). Metacognitive strategies can provide students with the opportunity and encourage them to learn, understand and recognize the information they receive while the classroom and in their daily lives (Helen, 2009).

\section{PROBLEM STATEMENT}

Metacognitive strategies are one of the most important learning strategies for determining success in learning, creative and critical thinking capabilities, the level of academic achievement and intellectual skills of a student The strength of these skills can be demonstrated in an educational system that emphasizes academic achievement as a measure of the success of a person in education. According to Mohamad and Mahamod (2014), students who know to solve a problem but fail to apply it correctly. As a result, students are less likely to apply the knowledge they have learned, the students thinking is evident and fails to think outside the box in a context only, including examinations (Ibrahim \& Iksan, 2017). This is because the metacognitive strategy is still under-emphasized and the application among teachers (Based on studies by the Ministry of Education, Malaysia, 2013). The high-level thinking among teachers and students in Malaysia is very inferior (Curriculum Development Division, 2012).

The serious impact of the education system in Malaysia is the failure of teachers in applying students thinking skills, including student achievement in international assessments. 
According to Abdullah et. al., (2012), the technical students did not master the metacognitive strategy well. This is because, it is likely that students have little knowledge of the strategies through previous learning and experience but do not know how to apply the strategy correctly and effectively (Mohamad \& Mahamod, 2014). In addition, the lessons learned by students in the lecture are insufficient for learning towards thinking skills (Md.Yunos et al., 2011). Thus, students are faced with difficulties in thinking skills due to the lack of detailed information. It is also emphasized by Salihudin (2014) that the observational study found that the application of thinking skills in the classroom was only at a minimum and this proved that the majority of teachers did not understand the method of mixing these thinking skills in teaching

\section{OBJECTIVE}

i. Identify the level of metacognitive awareness strategies among technical students.

ii. Identify the differences between level of metacognitive awareness strategies based on gender of students.

iii. Identify the differences between level of metacognitive awareness strategies based on the field of study of students.

\section{METHODOLOGY}

The research design is a survey method that uses quantitative approaches. For the design of the study, researchers conducted surveys to identify the level of metacognitive awareness strategies among technical students in polytechnics. The quantitative approach used by the researcher is a questionnaire. This study was conducted at Polytechnic Melaka and Polytechnic Port Dickson. A total of 361 technical students consisting of boys and girls were randomly selected as respondents.

Table 1: Number of Population and Samples of Study (Student Affairs Division, 2019)

\begin{tabular}{|c|c|c|c|}
\hline No & Polytechnic & Population & Sample \\
\hline 1 & $\begin{array}{c}\text { Polytechnic Port } \\
\text { Dickson }\end{array}$ & 4235 & 268 \\
\hline 2 & Polytechnic Melaka & 1461 & 93 \\
\hline \multicolumn{2}{|c}{ Total } & 5696 & 361 \\
\hline
\end{tabular}

The questionnaire consisted two parts. Part A is the items on respondent's demographics such as gender and field of study. Part B is a modified Metacognitive Awareness Inventory (MAI) item from Schraw \& Dennison (1994). Part $\mathrm{B}$ is used to examine metacognitive awareness among technical students in polytechnics. This instrument is divided into two main constructs. The first construct (B1) is knowledge about cognitive divided into three categories namely declarative knowledge, procedural knowledge and limited knowledge. While the second construct (B2) is a regulation of cognitive that is divided into five dimensions namely planning, information management, comprehension monitoring, debugging strategies and evaluation. Metacognitive awareness inventory (MAI) is determined by using incorrect and correct item scores. Table 2 shows the distribution, number and position of the instrument items.
Table 2: Distribution, number and position instrument items

\begin{tabular}{llcc}
\hline Parts & \multicolumn{1}{c}{ Aspect of Study } & $\begin{array}{c}\text { Number } \\
\text { of Items }\end{array}$ & $\begin{array}{c}\text { Item } \\
\text { Position }\end{array}$ \\
\hline A & $\begin{array}{l}\text { Demographics } \\
\text { B }\end{array}$ & 5 & 5-Jan \\
& $\begin{array}{l}\text { Awareness } \\
\text { Inventory } \\
\text { (MAI) }\end{array}$ & & \\
B1 & $\begin{array}{l}\text { Knowledge } \\
\text { about cognition } \\
\text { Regulation of } \\
\text { cognitive }\end{array}$ & 17 & 17-Jan \\
B2 & 35 & 18-52 \\
\hline
\end{tabular}

To analyze the problem of this study, descriptive statistics and inferential statistics are used. Descriptive statistics are used to summarize a set of data, while inferential statistics are used to create a summary of the population's perceptions based on the population sample data (Idris, 2013). For the question of a researcher using a descriptive statistical method to find percentage and frequency values. In this study, the researchers used 51 items as suggested by Schraw and Dennison (1994) as a research instrument. Metacognitive awareness instruments (MAI) are determined by using incorrect and correct item scores. Respondents fill out each answer by filling out (/) in the provided answer box. The scoring guide for the questionnaire is a mark given to the correct answer and the mark is empty on the marked answer. Next, the marks for each dimension on each construct are summed up. The level of metacognitive awareness strategies is measured by the number of mean scores obtained. Table 3 shows the score and mean score for each construct.

Table 3: Score and mean based on construct

\begin{tabular}{|c|c|c|c|}
\hline No & Parts & Score & $\begin{array}{l}\text { Mean } \\
\text { Score }\end{array}$ \\
\hline 1. & \multicolumn{3}{|l|}{ B1 : Knowledge about cognition } \\
\hline & a. Declarative knowledge & & 18 \\
\hline & b. Procedural knowledge & & 14 \\
\hline & c. Conditional knowledge & & 15 \\
\hline 2. & \multicolumn{3}{|l|}{ B2 : Regulation of cognition } \\
\hline & a. Planning & & 17 \\
\hline & $\begin{array}{l}\text { b. Information management } \\
\text { strategies }\end{array}$ & & $/ 10$ \\
\hline & $\begin{array}{l}\text { c. Comprehension } \\
\text { monitoring }\end{array}$ & & $/ 7$ \\
\hline & d. Debugging strategies & & 15 \\
\hline & e. Evaluation & & 16 \\
\hline & Total mean score & & 152 \\
\hline
\end{tabular}

The respondent's level awareness was categorized into three levels, namely low, medium and high levels. The level of interpretation of mean score of awareness of metacognitive strategy is determined as in Table 4.

Published By: 
Table 4: Interpretation level based on mean score (Konting, 2004)

\begin{tabular}{|c|c|}
\hline Mean score range & The tendency level \\
\hline $0.00-0.33$ & Low \\
\hline $0.34-0.66$ & Moderate \\
\hline $0.67-1.00$ & High \\
\hline
\end{tabular}

\section{RESULT AND DISCUSSION}

In this section, the researcher discusses the findings of the study to answer the three questions of the study.

\section{A. Metacognitive awareness strategy among technical students}

The findings of the study were to answer the question of the first study. The mean score, frequency and percentage are used to compare the number of students to the question of this study. Among the level of metacognitive awareness strategies are high levels, moderate and low levels. Based on Table 5, it can be seen that all eight dimensions are at a high level of interpretation. The dimensions under the knowledge about cognitive construct is procedures knowledge (mean score 0.83 ) are at the highest level. Then followed by conditional knowledge dimension (mean score 0.82) and declarative knowledge (min score 0.79).

Table 5: Mean score, standard deviation and interpretation for dimension of metacognitive strategy awareness.

\begin{tabular}{|l|c|c|c|}
\hline \multicolumn{1}{|c|}{ Dimension } & $\begin{array}{c}\text { Mean } \\
\text { skor }\end{array}$ & $\begin{array}{c}\text { Standard } \\
\text { deviatio } \\
\mathrm{n}\end{array}$ & $\begin{array}{c}\text { Interpretatio } \\
\mathrm{n}\end{array}$ \\
\hline $\begin{array}{l}\text { Procedural } \\
\text { knowledge }\end{array}$ & 0.83 & 0.183 & High \\
\hline $\begin{array}{l}\text { Declarative } \\
\text { knowledge }\end{array}$ & 0.79 & 0.235 & High \\
\hline $\begin{array}{l}\text { Conditional } \\
\text { knowledge }\end{array}$ & 0.82 & 0.203 & High \\
\hline $\begin{array}{l}\text { Information } \\
\text { management } \\
\text { strategies }\end{array}$ & 0.80 & 0.205 & High \\
\hline $\begin{array}{l}\text { Debugging } \\
\text { strategies }\end{array}$ & 0.79 & 0.178 & High \\
\hline Planning & 0.79 & 0.206 & High \\
\hline $\begin{array}{l}\text { Comprehension } \\
\text { monitoring }\end{array}$ & 0.83 & 0.197 & High \\
\hline Evaluation & 0.82 & 0.213 & High \\
\hline
\end{tabular}

Meanwhile, for dimensions under the regulation of cognitive construct comprehension monitoring (mean score 0.83 ) is at the highest level. This is followed by evaluation dimension (mean score 0.82 ) and information management strategy dimension (mean score 0.80 ). Finally, the planning dimension (min score 0.79) and the debugging strategies (min score 0.79) under the regulation of cognitive construct is the lowest. Based on Table 6, it is found that the constructs of knowledge about cognitive are higher than the cognitive regulation of constructs. Secondly, for cognitive of knowledge (mean score 0.81), cognitive regulation (mean score 0.80 ) shows that respondents have high level of interpretation and show the level of metacognitive awareness strategies among technical students in the high level of interpretation.

Table 6 : Mean score, standard deviation and interpretation for cognitive and cognitive knowledge of regulation.

\begin{tabular}{|l|c|c|c|}
\hline \multicolumn{1}{|c|}{ Constructs } & $\begin{array}{c}\text { Mea } \\
\mathrm{n}\end{array}$ & $\begin{array}{c}\text { Standard } \\
\text { deviatio } \\
\mathrm{n}\end{array}$ & $\begin{array}{c}\text { Interpretatio } \\
\mathrm{n}\end{array}$ \\
\hline $\begin{array}{l}\text { Knowledge } \\
\text { about } \\
\text { cognition }\end{array}$ & 0.81 & 0.163 & High \\
\hline $\begin{array}{l}\text { Regulation of } \\
\text { cognition }\end{array}$ & 0.80 & 0.157 & High \\
\hline $\begin{array}{l}\text { Level of } \\
\text { metacognitive } \\
\text { awareness } \\
\text { strategies }\end{array}$ & 0.81 & 0.149 & High \\
\hline
\end{tabular}

The findings show that for knowledge of cognitive, students are more likely to procedural knowledge dimensions, followed by conditional knowledge dimensions and declarative knowledge dimensions. For the procedural knowledge dimensions, students have a high degree of awareness of their intellectual strengths and weaknesses in studying, analyzing and formulating. This is because technical students in polytechnics will be given assignments and practical work to be solved individually or in groups that allow students to reflect on their learning and to identify their strengths and weaknesses (Coffey, 2009). However, students are found to be less able to remember something, and the students likely are trying to understand the learning in the classroom and result in the student's achievement at low-quality level (Baharom, 2012).

For regulation of cognition constructs, students tend to comprehension monitoring dimensions, followed by evaluation dimensions, and information management strategies dimensions and ultimately, the planning dimensions and debugging strategies. For comprehension monitoring dimensions, students are found to be able to change strategies if they fail to understand something, make an evaluation when mistaken and stop and re-read when mistaken. This is because technical students in polytechnics can control their learning process (Surat, 2013) and help students improve their academic performance (Ling, 2010).

\section{B. The difference between the level of metacognitive awareness strategies based on student gender}

The T-test (Independent) was used to analyze the study data for this question because the measured data of gender is in the form of nominal. The permissible level in T-test is at a significant level of $\rho=0.05$. The findings in Table 7, show that there is a significant difference between the level of metacognitive awareness strategies and the gender of students among technical students. The mean score for male students (mean score 0.82) was higher than female students (mean score 0.79 ). The level of metacognitive awareness of male strategies is higher than that of female students. Similar findings were obtained from the findings of Mohamad et al.,

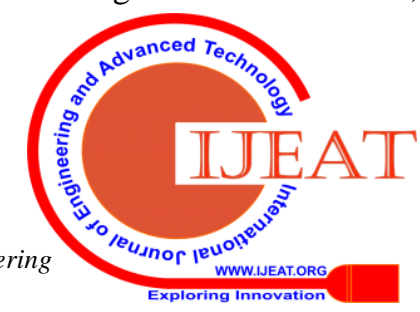


(2013), which showed that there was a difference between the metacognitive awareness strategies of student and gender factors. This is because, male students have a higher level of monitoring skills than female students. In addition, male students have multiple intelligences in applying various learning strategies to help improve their learning achievement (Mahamod, 2012).

Meanwhile, female students are found to have a higher level of metacognitive awareness than male students from assessing skills and regulatory skills. This is because female students have a high level of intelligence compared to male students (Mohamad et al, 2013). Furthermore, based on Abdul Hamid (2012) study, which found that there were significant differences based on gender in metacognitive strategies in the study of Malay Literature. The difference between gender is also likely to depend on the field of study itself. This can be seen from the findings of this study that male students have a higher level of metacognitive strategies than girls in technical fields. However, the findings of this study are contrary to the findings of Sanip and Che Ahmad (2014), among form four students who take Biology subjects. The study found that the metacognitive awareness that existed in the student did not have a significant difference between the gender. Furthermore, the results of the Ling study (2010) found that the students of Engineering Mathematics showed that there was no significant difference in the metacognitive strategy between male and female students.

Table 7 : T-test analysis for the different levels of awareness of metacognitive strategies based on student gender

\begin{tabular}{|c|c|c|c|c|}
\hline $\begin{array}{c}\text { Gende } \\
\mathrm{r}\end{array}$ & $\begin{array}{c}\text { Sampl } \\
\mathrm{e}\end{array}$ & $\begin{array}{c}\text { Mea } \\
\mathrm{n}\end{array}$ & $\begin{array}{c}\text { Standard } \\
\text { deviatio } \\
\mathrm{n}\end{array}$ & Significant value \\
\hline Male & 198 & 0.82 & 0.121 & 0.021 \\
\hline Female & 163 & 0.79 & 0.176 & \\
\hline
\end{tabular}

* Difference at level $\rho<.05$

\section{The difference between the level of metacognitive awareness strategies based on the field of study of students}

Analysis Of Variance (ANOVA) was conducted to see the significant differences between the level of awareness of metacognitive strategies based on the field of technical student study. The significant levels allowed in the ANOVA test are $\rho=0.05$. The findings of the study in Table 8 show that there is a significant difference between the level of metacognitive awareness strategies and the field of study of students. Among them are lecturer teaching techniques and learning environment exposure based on metacognitive strategies during the teaching and learning process in the classroom to stimulate and encourage students to review their thinking processes (Ibrahim \& Iksan, 2017). According to Che Kob (2016), lecturers should know the appropriate learning strategies for students before starting the teaching process in ensuring the effectiveness and quality of implementation for teaching and learning sessions.

As a result, the student's academic achievement has increased and has a positive impact on the teaching and learning process in the classroom. Furthermore, teaching and learning activities conducted by lecturers to students in the classroom for a particular field are different and cause the level of awareness of metacognitive strategies different. This is because the different teaching and learning activities in the classroom are able to move the mind process in completing the assignment, oral examination, workshop and practical work, discussion process and brainstorming (Rahayah, 2010). The results of this study were supported by Abu Hassan et al. (2017) that there is a significant difference in the level of metacognitive awareness strategies from the aspect of cognitive awareness in the learning of Islamic Education between the fields of Science and Humanities.

Table 8 : Analysis of ANOVA for the different levels of awareness of metacognitive strategies based on the field of study of students

\begin{tabular}{|l|c|c|c|c|}
\hline \multicolumn{1}{|c|}{$\begin{array}{c}\text { Field of } \\
\text { Study }\end{array}$} & $\begin{array}{c}\text { Sampl } \\
\mathrm{e}\end{array}$ & Mean & $\begin{array}{c}\text { Standard } \\
\text { deviation }\end{array}$ & $\begin{array}{c}\text { Significan } \\
\text { t value, } \rho\end{array}$ \\
\cline { 1 - 4 } $\begin{array}{l}\text { Electrical } \\
\text { engineering }\end{array}$ & 121 & 0.82 & 0.137 & \multirow{2}{*}{0.016} \\
\cline { 1 - 4 } $\begin{array}{l}\text { Civil } \\
\text { engineering }\end{array}$ & 132 & 0.78 & 0.160 & \\
\cline { 1 - 4 } $\begin{array}{l}\text { Mechanical } \\
\text { engineering }\end{array}$ & 108 & 0.83 & 0.146 & \\
\hline
\end{tabular}

$*$ Difference at level $\rho<.05$

\section{CONCLUSION AND RECOMMENDATIONS}

The result of this study showed that technical students at Melaka Polytechnic and Port Dickson Polytechnic had a high level of metacognitive awareness. Besides, there was a significant difference between the level of metacognitive awareness strategies based on gender and field of study. Consequently, overall students have an active awareness in the regulation of cognition and have knowledge about cognitive in achieving better learning goals. This study can help all parties to know their strengths and weaknesses; and strive to enhance their potential in acquiring high levels of skills and knowledge.

Based on the results of the research, the researcher suggested a few suggestions for improvement purposes for the parties involved. Polytechnics requires to ensure that lecturers apply metacognitive strategies in the teaching and learning process. The polytechnics should publish a module that contains techniques in using metacognitive strategies in teaching and learning as a guide to students. The polytechnics can organize workshops and courses of learning metacognitive strategies in pursuit and learning so that students can learn the right techniques to enhance their metacognitive strategies further. Lecturers need to further extend scientific references and information in learning using metacognitive strategies in teaching and learning. Students should be aware of their level of metacognitive strategy, and indirectly they can identify weaknesses and strengths in learning metacognitive strategies. Therefore, students can improve and improve their weaknesses in order to have right metacognitive strategies in learning.

Published By: 


\section{REFERENCES}

1. Abdul Hamid, S. (2012). Amalan Meta Kognitif Dalam Kalangan Murid Ketika Belajar Komponen Sastera. Kertas Projek Sarjana Pendidikan. Fakulti Pendidikan, UKM Bangi.

2. Abdullah, A. G. K., Ismail, A., Abdullah, M. H. \& Purba, M. (2012). Acquired And Required Competencies In Manufacturing Sector Graduates From Employers' And Employees. Perspective : The Malaysia Case Educ. Res. 2013, 3(2) : 126-136.

3. Abu Hassan, K., Hamzah, M. I., \& Lubis, M. A. (2017). Tahap Kemahiran Metakognitif Murid Sekolah Menengah di Kawasan Felda dalam Pembelajaran Pendidikan Islam. ASEAN Comparative Education Research Journal On Islam and Civilization. 1(1), 94-106.

4. Baharom. S., Hamid, R., \& Hamzah, N., (2012). Development of a Problem Based Learning in Concrete Technology Laboratory Work. Procedia-Social And Behavioural Sciences 60.9 (2012), 8-13.

5. Che Kob, C. G. (2016). Amalan Gaya Pembelajaran Pelajar Cemerlang Di Politeknik Seberang Perai: Kajian Pelajar Malaysia Berdasarkan Model Felder Silvermen. Malaysian Journal of Society and Space 12 issue 3 (181-191) 181.

6. Coffey, H. (2009). The relationship between metacognitive and writing in sixth grade mathematics. Unpublished Doctoral Dissertation, Walden Universiti, Walden.

7. Helen, N. (2009). Metacognitive Strategies on Classroom Participation and Student Achievement in Senior Secondary School Science Classrooms. Science Education International, 20(1), 25-31.

8. Ibrahim, N. H., \& Iksan, Z. (2017). Strategi metakognitif untuk kemahiran berfikir aras tinggi dalam proses pengajaran dan pembelajaran. Simposium Pendidikan diPeribadikan: Perspektif Risalah An-Nur (SPRiN2017).

9. Kassim, N., \& Zakaria, E. (2015). Integrasi Kemahiran Berfikir Aras Tinggi dalam Pengajaran dan Pembelajaran Matematik: Analisi Keperluan Guru. Proceeding book Education Gradute Regional. Conference in Counseling Centre Profesional Counselor Education Laboratory in the State University of Medan. Jan 2015, p. 60-67.

10. Ling A. Y. L. (2010). Kemahiran metakognitif pelajar kejuruteraan dalam menyelesaikan masalah matematik kejuruteraan. Jurnal Sains Dan Matematik. 2(2)(2010) : 75-84.

11. Mahamod,Z., Abdul Hamid, S., Timbang, T., Haron, A. R. \& Muhamad, Z. (2012). Amalan Meta Kognitif dalam Kalangan Murid Ketika Belajar Komponen Sastera. Proceedings International Seminar Educational Comparative Competency Based Curriculum Between Indonesia and Malaysia, 157-172

12. Mohamad, N. A. \& Mahamod, Z. (2014). Tahap Kemahiran Metakognitif Murid Tingkatan Empat dalam Pembelajaran Bahasa Melayu. Jurnal Pendidikan Bahasa Melayu. 4(1), 41-47.

13. Md Yunos, J. (2011). Technical \& Vocational Education \& Training (TVET) from Malaysia Perspective. $2^{\text {nd }}$ International TT-TVET EU-Asia-Link Project Meeting, VEDC Malang, Indonesia.

14. Rahayah, S. \& Azaheen, N. (2010). Kemahiran Pemikiran Kritikal Dan Penyelesaian Masalah Pelajar -Pelajar Sains. Prosiding Seminar Kebangsaan Pendidikan Negara Kali Ke-4.

15. Salihudin, M.S. (2014). Penguasaan pelajar dalam kemahiran berfikir aras tinggi dengan pembelajaran kaedah Socratik. Konvensyen Antarabangsa Jiwa Pendidik. 2014.

16. Sanip, F. A., \& Che Ahmad, C. N., (2014). Penilaian Kesedaran Strategi Metakognitif Dan Kemahiran Berfikir Aras Tinggi Dalam Kalangan Pelajar Biologi. Jurnal Penyelidikan Pendidikan (KPM) Jilid 15

17. Sima Khezrlou (2012). The Relationship Between Cognitive and Metacongnitive Strategies, Age and Level Of Education. The Reading Matrix 2012. 12( 1), April 2012

18. Surat, S., Ramli, S. \& Rahman, S. (2013). Sumbangan Elemen Metakognitif Terhadap Pencapaian Penulisan Karangan. Jurnal Pendidikan Bahasa Melayu. 3(2), 79-91.

19. Surat, S., (2012). Keberkesanan strategi 4-Meta dalam aktiviti penulisan Bahasa Melayu pelajar Tingkatan 4 (Tesis Doktor Falsafah). Fakulti Pendidikan, Universiti Kebangsaan Malaysia, Bangi.

20. Zimmerman, B. J., \& Schunk, D. H. (2011). Self-Regulation of Learning and Performance. International Journal of Technology and Design Education, 23(3), 489-517

\section{AUTHORS PROFILE}

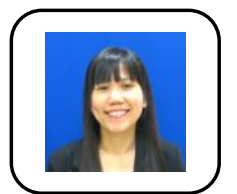

Dr Yee Mei Heong is the senior lecturer for the Department of Engineering Education (JPK) at the Faculty of Technical and Vocational Education of Universiti Tun Husseion Onn of Malaysia (UTHM). She graduated with a Bachelor of Technology in Education (Civil Engineering) with honors at the Universiti Teknologi Malaysia in 2002 and then went on to pursue a Master of Technical and Vocational Education at the Universiti Teknologi Malaysia in 2005. She received a master's degree in Doctor of Education Philosophy Engineering and Vocational at Universiti Tun Hussein Onn Malaysia in 2015. She has teaching experience as a Graduate Educational Services Officer at Maktab Rendah Sains MARA Gerik, Perak for 3 years and a senior lecturer at UTHM for 10 years. She is currently the chair of the Doctor of Education Philosophy Program since 2014. She also served as chair of the brick lab in 2014-2016. Her academic expertise includes teaching and learning problem solving skills. She has published over 90 articles journals / teaching modules / books / book chapters in his area of expertise.

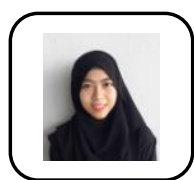

The author was born on June 10, 1995 in Sri Aman, Sarawak. She is from Gurun, Kedah. She received her early education in Sekolah Kebangsaan Sulaiman, Bentong Pahang and received her secondary education at Sekolah Menengah Kebangsaan Batu 5, Gurun Kedah. She was furthered her education in Polytechnic Sultan Abdul Halim Mu'adzam Shah at Jitra, Kedah. Subsequently, in 2016 she pursued her undergraduate studies at Universiti Tun Hussein Onn Malaysia (UTHM) in Parit Raja, Johor. At UTHM, she followed undergraduate studies in Vocational Education (Building Construction) and eventually wrote a thesis report of Bachelor of Project which was entitled "Level of Metacognitive Awareness Strategies Among Technical Students" to fulfilled graduation requirements in 2020. She was also actively involved in the curriculum activities at UTHM as treasurer of the UTHM Sekretariat Angkatan Mahasiswa Anti Rasuah (AMAR) club.

Che Wan Husna Syahirah Bt Che Wan Razak, is a master student of technical and vocational education, Universiti Tun Hussein Onn Malaysia (UTHM). She graduated degree in Bachelor of Vocational Education (Building Construction) from UTHM in 2018. She currently doing her research in Problem Based Learning using Inventive Problem Solving Theory (TRIZ). The author is also a practitioner of TRIZ (Inventive Problem Solving Theory).

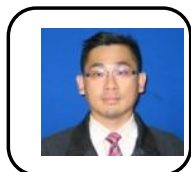

Tee Tze Kiong was born in Melaka, Malaysia on the $25^{\text {th }}$ of April, 1979. He obtained his first degree in bachelor of technology with education (civil engineering) at the Faculty of Education, Universiti Teknologi Malaysia, Skudai, Johor, Malaysia in 2002. In 2003, he completed his Master's degree in technical and vocational education at University Teknologi Malaysia, Skudai, Johor, Malaysia in. At the year 2013, he obtained his Ph.D in technical and vocational education at Universiti Tun Hussein Onn Malaysia, Batu Pahat, Johor, Malaysia. His Ph.D. research focuses on higher order thinking skills and Buzan Mind Mapping. His working experiences include secondary school teacher, subject matter expert, e-tutor, e-grader, proctor for final examination at Open University Malaysia, industrial practicum supervisor, undergraduate project, master and Ph.D. thesis supervisor, undergraduate, master and Ph.D. examiner, subject matter expert and examiner in Technical and Vocational Education courses, professional consultant for Multiple Intelligent Tests and Learning Styles Inventory, instrument construction workshop, senior lecturer and head of department of Engineering Technology at Sultan Idris Education University. Now, he is a lecturer in the Department of Professional Education, Faculty of Technical and Vocational Education, at Universiti Tun Hussein Onn Malaysia. (Email tktee@uthm.edu.my). Current and previous research interests are thinking skills, thinking tools, self-instructional modular approach, learning styles and inventive problem-solving skills. Dr. Tee is a member of Universiti Teknologi Malaysia Alumni, Universiti Tun Hussein Onn Malaysia Alumni, Malaysia Technical and Vocational Education Association and TRIZ level I instructor.

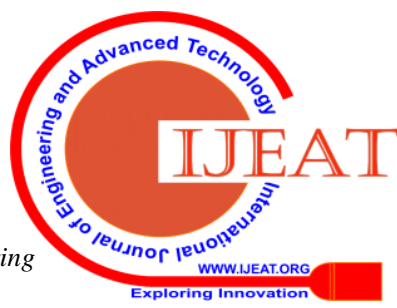


Prof. Madya Ts. Dr. Kok Boon Ching obtained his Bachelor's degree (Electrical Engineering), Master's degree (Electrical Engineering) and Doctor of Philosophy (Electrical Engineering) respectively in 1998, 2002 and 2009 from Universiti Teknologi Malaysia (UTM). From 1998 to 1999, he served in the Engineering Department, Likom Technology Sdn. Bhd., As a Product Engineer. He also served at TNB Research Sdn. Bhd. (TNBR) as a researcher from 2001 to 2003. He has been in the field of higher education since 2004 at the Department of Electrical Engineering (JEK), Faculty of Electrical and Electronic Engineering (FKEE), University of Tun Hussein Onn Malaysia (UTHM). He currently serves as an Associate Professor at UTHM. His areas of expertise include electrical power systems, renewable energy, energy harvesting systems, Continuous High Voltage (HVDC) and revenue-based education (OBE). He has been providing OBE related advisory services to the Vocational College (KV), National Youth Skills Institute (IKBN) and Southern University College since 2015. He has published more than 70 articles / journals / teaching modules / book chapters in his area of expertise. He has been a registered member of the Board of Engineers of Malaysia (BEM) since 1998. Currently, he is also a member of the IEEE international professional body and a graduate of the Malaysian Institute of Engineers (IEM) 